Jurnal Teknologi, 36(A) Jun. 2002: 1-12

(C) Universiti Teknologi Malaysia

\title{
PAD BREK KENDERAAN PERSENDIRIAN: KAJIAN KE ATAS MIKROSTRUKTUR LAPISAN PINDAH
}

\author{
R.J. TALIB ${ }^{1}$, A. MUCHTAR ${ }^{2} \&$ C.H. AZHARI ${ }^{3}$
}

\begin{abstract}
Abstrak. Mikrostruktur permukaan bahan geseran brek beransur berubah dengan peningkatan masa pembrekan dan beban kenaan. Setiap sampel menjalani ujian geseran dengan lima beban kenaan $(100 \mathrm{~N}, 200 \mathrm{~N}, 400 \mathrm{~N}, 600 \mathrm{~N}, 800 \mathrm{~N})$ dan masa pembrekan yang berlainan (3, 6, 9, 12, 15 minit). Perubahan permukaan sampel diperhatikan selepas setiap kali menjalani ujian geseran dengan menggunakan teknik kemikroskopan elektron imbasan. Pada permulaan pembrekan, proses adunan bahan pindah berlaku. Pembrekan seterusnya menyebabkan berlaku urutan perubahan lapisan pindah seperti berikut; (i) pembentukan tampalan pindah, (ii) penjanaan lapisan menutupi permukaan secara menyeluruh, (iii) pembentukan lapisan pindah berbilang, dan (iv) lapisan pindah paparan lebur. Penelitian ke atas bahan yang dikaji menunjukkan darjah perubahan permukaan haus menjadi lebih intensif dengan peningkatan masa pembrekan dan beban kenaan.
\end{abstract}

Kata Kunci: $\quad$ pad brek, ujian geseran, MEI, tampalan pindah, lapisan pindah

\begin{abstract}
Surface microstructures of brake friction materials gradually change with increase in braking time and applied loads. Each sample is subjected to five different applied loads (100 N, $200 \mathrm{~N}$, $400 \mathrm{~N}, 600 \mathrm{~N}, 800 \mathrm{~N})$ and braking times (3, 6, 9, 12, 15 minutes). The surface changes were observed after each friction test by using scanning electron microscopy technique. A process of mixed transfer materials was observed upon the onset of braking. With subsequent brakings, the following sequence of changes on transfer materials was observed; (i) formation of patches of transfer material, (ii) generation of continuous transfer materials, (iii) formation of multilayer of transfer materials, and (iv) formation of transfer material that behaves like a fluid. Investigation on the SEM micrographs showed that the degree of surface changes became severe with increase in braking times and applied loads.
\end{abstract}

Keywords: brake pad, friction test, SEM, transfer patches, transfer layers

\subsection{PENGENALAN}

Permukaan bahan lazimnya adalah kasar pada skala mikroskopik. Kekasaran permukaan $\left(R_{\text {maks }}\right)$ empat jenis pad brek semasa ujian geseran adalah antara 8.4 hingga ke $77.7 \mu \mathrm{m}[1]$. Titik sentuhan sebenar yang berlaku dikenali sebagai persimpangan sementara jumlah kawasan sentuhan individu persimpangan dikenali sebagai kawasan

\footnotetext{
${ }^{1}$ Advanced Materials Research Centre (AMREC), SIRIM Bhd,. Lot 34, Jalan Hi-Tech 2/3, Kulim Hi-Tech Park, 09000 KULIM, Malaysia. Tel: 04-4017166. Fax: 04-4033224. e-mail: talibria@sirim.my ${ }^{2}$ Universiti Kebangsaan Malaysia, 43600 UKM Bangi, Malaysia. Tel: 03-89296520. Fax: 03-89259659. e-mail: muchtar@vlsi.eng.ukm.my

${ }^{3}$ Faculty of Engineering, Universiti Kebangsaan Malaysia, 43600 UKM Bangi, Malaysia. Tel: 03-89292077. Fax: 03-89264816. e-mail: mek@vlsi.eng.ukm.my
} 
sentuhan sebenar. Nisbah kawasan sentuhan sebenar dengan kawasan ketara adalah kecil antara $10^{-2}$ hingga $10^{-5}$ [2]. Ciri kekasaran permukaan mempengaruhi jumlah pembentukan persimpangan dan nisbah sentuhan sebenar dengan sentuhan ketara.

Lapisan pindah akan bercampur dengan bahan yang tersingkir dari permukaan dan dari cebisan serpihan berselerak yang baru pindah [3]. Selepas beberapa lama bergelangsar lapisan adunan bahan pindah akan terbentuk yang mana sebahagian kecilnya akan tersingkir sebagai puing haus dan selebihnya kekal sebagai lapisan pindah [4]. Lapisan pindah terjana di atas pad dan piring brek terhasil dari mampatan puing haus yang terjana dari permukaan bahan yang bergelangsar [5]. Rekatan lapisan pindah menjadi lemah dengan peningkatan suhu permukaan. Siwei [6] juga mendapati lapisan pindah terus terjana dan diricih di antara muka piring brek dan pad brek.

Akagaki dan Rigney [7] mendapati bahawa fenomenon saling pindah berlaku semasa proses geseran gelangsar logam tulen seperti $\mathrm{Cu}, \mathrm{Ni}$, Fe dan Mo. Perpindahan berlaku dari julat perpindahan terserak setempat kepada perpindahan nisbi setara. Rekatan bahan yang bergelangsar bergantung dengan kesesuaian pasangan bahan, sifat dan kebersihan permukaan, tenaga permukaan, keadaan sentuhan dan agihan beban.

Puing haus terjana dari lapisan pindah yang telah menjalani proses adunan bahan terpindah yang komplek semasa gelangsar dan bukannya terjana terus dari bahan asas. Penyingkiran puing haus berlaku apabila ketebalan kritikal bahan adunan pindah pada permukaan telah menjadi stabil [8]. Puing haus yang tersingkir dari permukaan mempunyai kandungan, struktur dan kekerasan yang sama dengan bahan adunan pindah terhasil semasa gelangsar [9].

Kajian yang dijalankan adalah bertujuan untuk meneliti proses penjanaan lapisan pindah pada permukaan haus bahan geseran brek dengan peningkatan masa pembrekan dan beban kenaan.

\subsection{BAHAN DAN KAEDAH KAJIAN}

Satu jenis pad brek untuk kenderaan persendirian telah diperolehi dari pasaran tempatan. Kandungan bahan logam di dalam pad brek diperolehi dengan menggunakan Mikroskop Elektron Imbasan (MEI) berserta Analisis Tenaga Terserak Sinar-X (EDAX). Kandungan komposisi bahan logam di dalam pad brek dan piring brek ditunjukkan dalam Jadual 1 dan 2. Pad brek yang dikaji ditandakan dengan A, B, C D, dan E bagi setiap beban kenaan yang berlainan. Setiap sampel A, B, C, D, dan E pula ditandakan dengan subskrip 1, 2, 3, 4, dan 5 bagi setiap masa pembrekan yang berlainan. Penandaan sampel dan subskrip pada sampel adalah seperti ditunjukkan pada Jadual 3 dan 4 . Sampel bersaiz 20 $\pm 1 \mathrm{~mm} \times 30 \pm 1 \mathrm{~mm} \times 15 \pm 1 \mathrm{~mm}$ dipotong daripada plat sokong pad brek dengan menggunakan gergaji besi. Selepas dicuci, sampel tersebut dipasang pada pemegang pad brek dengan menggunakan perekat jenis ATE dan seterusnya diawet di dalam ketuhar pada suhu $180^{\circ} \mathrm{C}$ selama 1 jam (Spesifikasi Pembuat, ATE German). Seterusnya permukaan 
Jadual 1 Kandungan bahan dalam pad brek

\begin{tabular}{|c|c|}
\hline Bahan & $\begin{array}{c}\text { Peratus berat } \\
\text { kandungan } \\
\text { bahan (\%) }\end{array}$ \\
\hline MgK & 1.385 \\
AlK & 2.382 \\
SiK & 4.968 \\
S K & 5.887 \\
K K & 0.612 \\
CaK & 0.871 \\
TiK & 5.376 \\
FeK & 78.52 \\
\hline Jumlah & 100 \\
\hline
\end{tabular}

Jadual 3 Penandaan sampel

\begin{tabular}{|c|c|}
\hline $\begin{array}{c}\text { Penandaan } \\
\text { sampel }\end{array}$ & $\begin{array}{c}\text { Beban } \\
\text { kenaan (N) }\end{array}$ \\
\hline A & 100 \\
B & 200 \\
C & 400 \\
D & 600 \\
E & 800 \\
\hline
\end{tabular}

Jadual 2 Kandungan bahan dalam piring brek

\begin{tabular}{|c|c|}
\hline Bahan & $\begin{array}{c}\text { Peratus berat } \\
\text { kandungan } \\
\text { bahan (\%) }\end{array}$ \\
\hline $\mathrm{Fe}$ & 94.32 \\
$\mathrm{C}$ & 2.75 \\
$\mathrm{SiK}$ & 2.10 \\
$\mathrm{Si}$ & 0.83 \\
\hline Jumlah & 100 \\
\hline
\end{tabular}

Jadual 4 Penandaan Subskrip sampel

\begin{tabular}{|c|c|}
\hline Subskrip & $\begin{array}{c}\text { Masa } \\
\text { pembrekan } \\
\text { (minit) }\end{array}$ \\
\hline Tanpa subskrip & Sebelum pengujian \\
Subskrip 1 & 3 \\
Subskrip 2 & 6 \\
Subskrip 3 & 9 \\
Subskrip 4 & 12 \\
Subskrip 5 & 15 \\
\hline
\end{tabular}

sampel dilas dengan kertas pasir bergred 300 kersik sebelum menjalani ujian geseran. Ujian geseran dijalankan dengan menggunakan mesin ujian bahan geseran berjenama Schenck (Rajah 1).

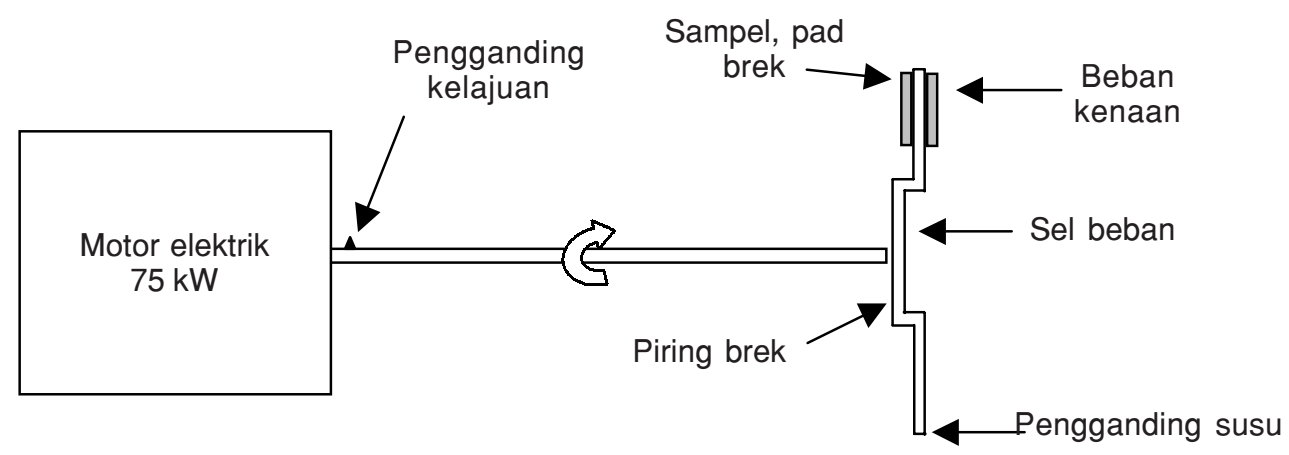

Rajah 1 Skema mesin ujian bahan geseran 
Kelajuan semasa ujian geseran adalah malar sepanjang masa ujian iaitu $11 \mathrm{~m} / \mathrm{s}$ (36 $\mathrm{km}$ sejam). Beban normal yang dikenakan ialah 100, 200, 400, 600 dan 800 N. Masa pembrekan yang dijalankan ialah 3, 6, 9, 12 dan 15 minit. Selepas menjalani ujian geseran, sampel dibiarkan sejuk hingga ke suhu bilik sebelum dibersihkan dengan udara mampat sekali lagi serta dicuci dengan kertas tisu. Sampel untuk pemeriksaan mikrostruktur permukaan di potong dari pemegang pad brek dengan menggunakan gergaji besi dan dicuci dengan kertas tisu. Saiz sampel ialah $10 \pm 1 \mathrm{~mm} \times 10 \pm 1 \mathrm{~mm}$ $\times 5 \pm 1 \mathrm{~mm}$ (panjang $\times$ lebar $\times$ tebal). Sampel disimpan di dalam kebuk yang mengandungi bahan pengering sebelum menjalani pemeriksaan mikrostruktur permukaan.

Sampel untuk pemeriksaan mikrostruktur subpermukaan dipotong dari pemegang pad brek dengan menggunakan gergaji besi dan seterusnya dicuci dengan kertas tisu. Kemudian sampel menjalani proses cagak sejuk. Seterusnya sampel dipotong merentas dan selari dengan arah gelangsar dengan menggunakan mesin pemotong halus berjenama Heiwa. Permukaan spesimen yang telah dipotong dilas dengan kertas pasir bergred 1200 kersik dengan menggunakan mesin pencanai berjenama Struers Knuth Rotor-3. Akhirnya permukaan tersebut digilap dengan menggunakan penggilap berjenama Metaserv dengan kekasaran $3 \mu \mathrm{m}$. Sebelum menjalani pemeriksaan kemikroskopan, sampel disalut dengan lapisan emas (ketebalan 5-50 nm) untuk mendapatkan keberkondukan sampel dengan sistem Kemikroskopan Elektron Imbasan. Peralatan salutan emas yang digunakan adalah berjenama Polaron Sputter Coater SC502.

Pemeriksaan kemikroskopan telah dijalankan dengan menggunakan mikroskop elektron imbasan jenis PHILLIPS XL 40. Voltan operasi kendalian adalah pada 10, 15, 20 dan $25 \mathrm{KeV}$ mengikut imej yang diambil. Pemeriksaan kemikroskopan dibuat dengan menggunakan pembesaran antara $100 \times$ hingga $10000 \times$.

\subsection{KEPUTUSAN DAN PERBINCANGAN}

Permukaan haus bahan geseran brek pada skala mikroskopik adalah tidak rata (menggerutu) serta mempunyai puncak dan lembah (Rajah 2). Permukaan haus masih bergerutu pada skala mikroskopik walaupun masa pembrekan dan beban kenaan ditingkatkan (Rajah 3). Kajian yang dijalankan oleh Talib dan Che Husna [1] mendapati permukaan haus bertambah licin; nilai kekerasan permukaan sebelum menjalani ujian melebihi $100 \mu \mathrm{m}$ yang kemudiannya menurun kepada $33.6 \mu \mathrm{m}$ selepas pembrekan selama 1,600 saat. Sentuhan pada puncak gerutu menyebabkan berlakunya ikatan pada permukaan. Sentuhan yang berulang menyebabkan ubah bentuk plastik pada puncak gerutu dan seterusnya penjanaan ubah bentuk substruktur [10]. Ubah bentuk substruktur menyebabkan bahan tidak stabil kepada ricih setempat. Fenomenon ketidakstabilan ricih setempat dan rekatan menyebabkan berlaku perpindahan serpihan bahan kepada permukaan bertentangan. 


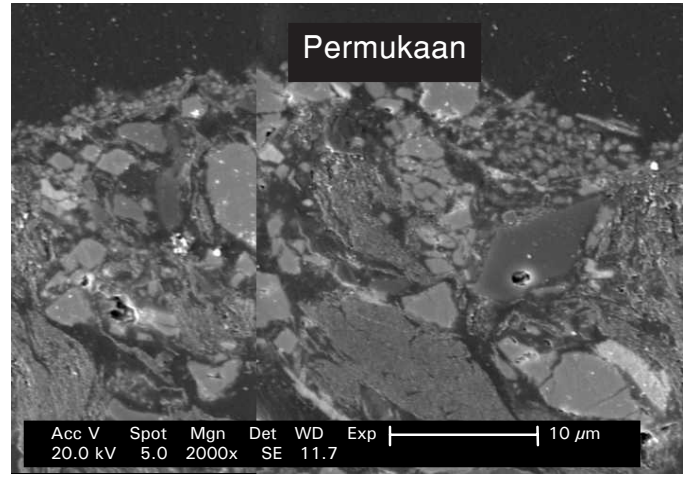

Rajah 2 Permukaan bergerutu selepas pembrekan selama 3 minit. Sampel B1 $(\times 2 \mathrm{~K})$, beban kenaan $200 \mathrm{~N}$ dan masa pembrekan 3 minit. Jarak di antara puncak ke puncak $34 \mu \mathrm{m}$ dan jarak antara puncak dengan lembah $8 \mu \mathrm{m}$.

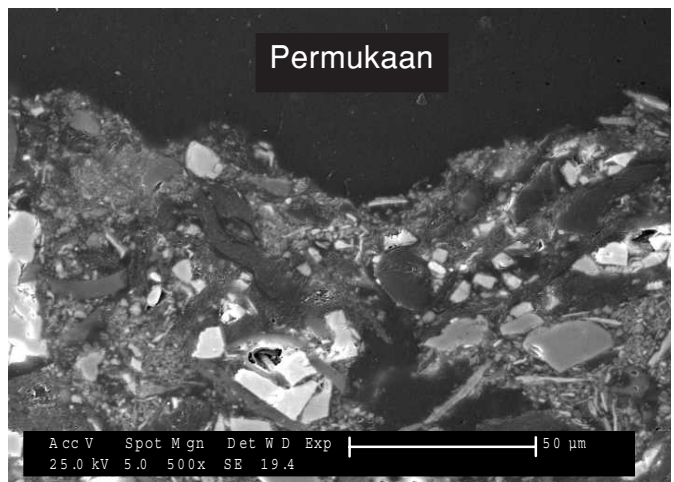

Rajah 3 Permukaan masih menggerutu apabila beban kenaan ditingkatkan. Sampel C5 $(\times$ 500), beban kenaan $400 \mathrm{~N}$ dan masa pembrekan 15 minit. Jarak antara puncak ke puncak $160 \mu \mathrm{m}$ dan jarak antara puncak dengan lembah $30 \mu \mathrm{m}$.

Proses pembentukan bahan teradun mekanik turut berlaku semasa gelangsar bahan geseran pad brek separa logam dengan piring brek yang diperbuat dari besi tuang kelabu pearlitik. Proses adunan ini mula berlaku pada pembrekan pertama (3 minit) dengan beban kenaan $100 \mathrm{~N}$ (Rajah 4). Peningkatan masa pembrekan seterusnya menyebabkan adunan bahan pindah membentuk adunan lapisan pindah pada permukaan pad brek (Rajah 5). Peningkatan beban kenaan juga menyebabkan pembentukan adunan lapisan pindah secara menyeluruh di atas permukaan seperti yang ditunjukkan dalam Rajah 6. Lapisan pindah yang terjana mengandungi $\mathrm{Fe}, \mathrm{Mg}$, Al, Si dan Ti (Rajah 7 dan Jadual 5). Semua bahan ini merupakan sebahagian dari bahan asas pad brek dan piring brek. Jacko et al. [5] juga mendapati fenomenon yang

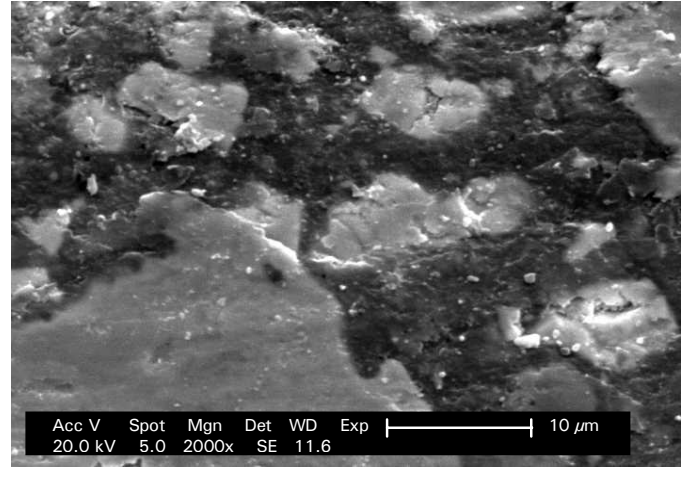

Rajah 4 Permulaan proses adunan bahan. Sampel A1 $(\times 2 \mathrm{~K})$, beban kenaan $100 \mathrm{~N}$ dan masa pembrekan 3 minit.

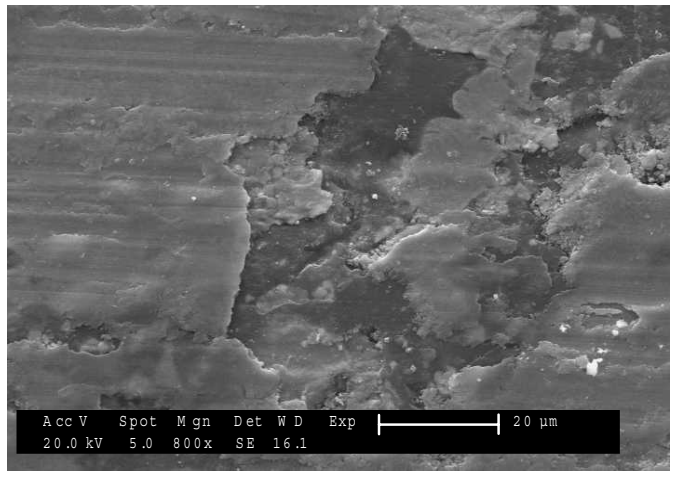

Rajah 5 Peningkatan beban kenaan menyebabkan pembentukan lapisan pindah. Sampel C1 $(\times 800)$, beban kenaan $400 \mathrm{~N}$ dan masa pembrekan 3 minit. 
Jadual 5 Kandungan unsur pada lapisan pindah

\begin{tabular}{|c|c|c|c|c|c|}
\hline \multirow{2}{*}{ Bahan } & \multicolumn{5}{|c|}{ Peratus berat kandungan bahan (\%) } \\
\cline { 2 - 6 } & Sampel A2 & Sampel B3 & Sampel C2 & Sampel C4 & Sampel D3 \\
\hline $\mathrm{Mg}$ & 2.025 & 3.258 & 3.872 & 6.897 & 5.661 \\
$\mathrm{Al}$ & 2.783 & 3.442 & 2.987 & 4.789 & 7.254 \\
$\mathrm{Si}$ & 0.447 & 0.752 & 0.596 & 0.91 & 21.764 \\
$\mathrm{Ti}$ & 0.58 & 0.578 & 0.829 & 1.782 & 8.819 \\
$\mathrm{Fe}$ & 94.165 & 91.97 & 91.716 & 85.622 & 56.502 \\
\hline Jumlah & $100 \%$ & $100 \%$ & $100 \%$ & $100 \%$ & $100 \%$ \\
\hline
\end{tabular}

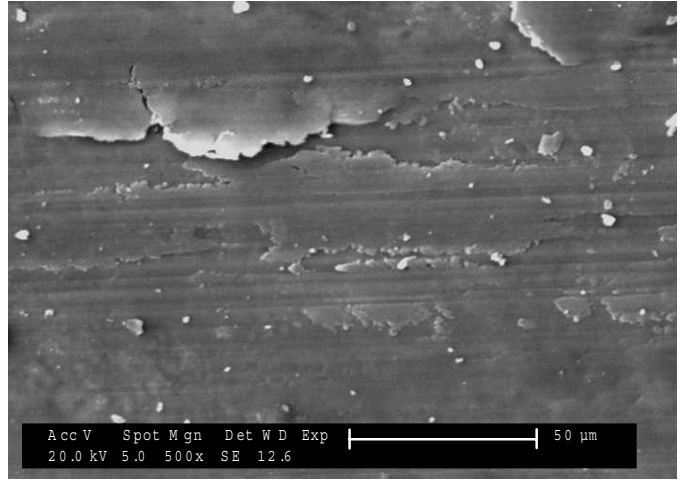

Rajah 6 Seterusnya lapisan pindah dipepat menutupi permukan haus secara keseluruhan. Sampel C2 (×500), beban kenaan $400 \mathrm{~N}$ dan masa pembrekan 6 minit.

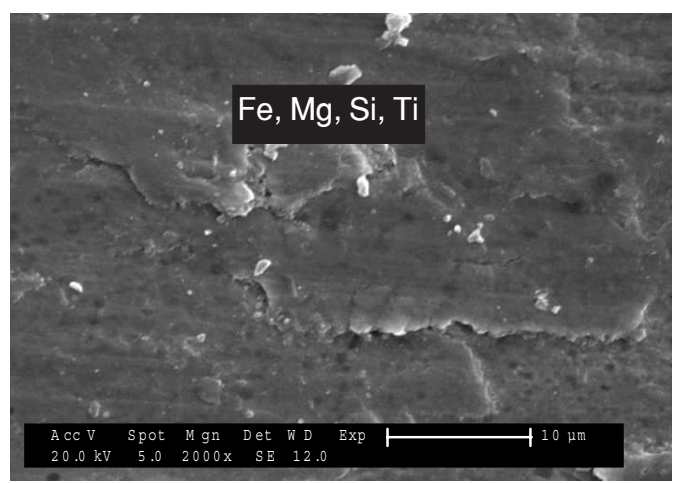

Rajah 7 Lapisan pindah mengandungi bahan logam Fe, Mg, Si, dan Ti. Sampel D4 (× 700), beban kenaan $600 \mathrm{~N}$ dan masa pembrekan 12 minit.

sama berlaku semasa pembrekan, yang mana lapisan pindah yang terbentuk pada permukaan pad brek mengandungi bahan dari pad brek dan piring brek.

Mikrostruktur permukaan menunjukkan berlaku proses pembentukan dan ricihan tampalan pindah ke atas permukaan haus pada pembrekan selama 3 minit (Rajah 8). Proses ini berlaku walaupun beban kenaan ditingkatkan dari $100 \mathrm{~N}$ hingga $800 \mathrm{~N}$. Penjanaan ubah bentuk plastik telah berlaku semasa proses ini dan telah menyebabkan permukaan dan subpermukaan tidak stabil kepada tegasan (Rajah 9). Proses ini menyebabkan terjana urutan tiga fenomenon iaitu; (i) perpindahan dua hala, (ii) calitan permukaan, dan (iii) pembentukan tampalan pindah. Proses adunan lapisan pindah dengan bahan yang tersingkir dari kedua permukaan turut berlaku semasa pembrekan. Seterusnya berlaku proses pembentukan lapisan pindah. Lapisan pindah didapati telah diricih, dimampat dan dipepat di atas permukaan bahan yang dikaji (Rajah 10).

Lapisan pindah terbentuk ke atas pad dan piring brek hasil dari mampatan puing haus yang terjana dan serpihan bahan yang baru pindah. Kadar pembentukan lapisan 


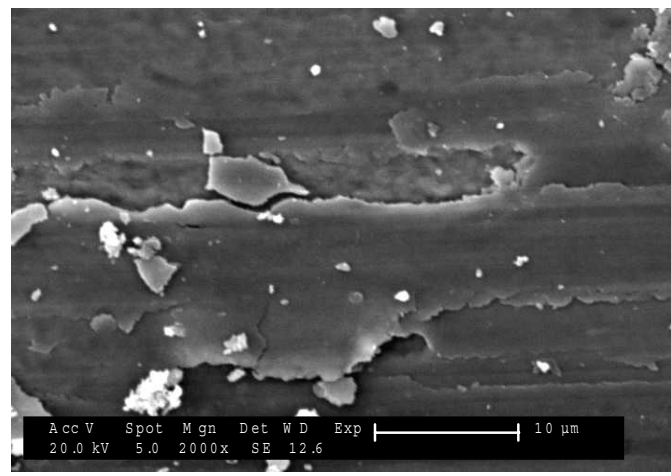

Rajah 8 Tampalan pindah tanggal dan berpindah disebabkan oleh rekatan. Sampel C1 $(\times 2 \mathrm{~K})$, beban kenaan $400 \mathrm{~N}$ dan masa pembrekan 3 minit.

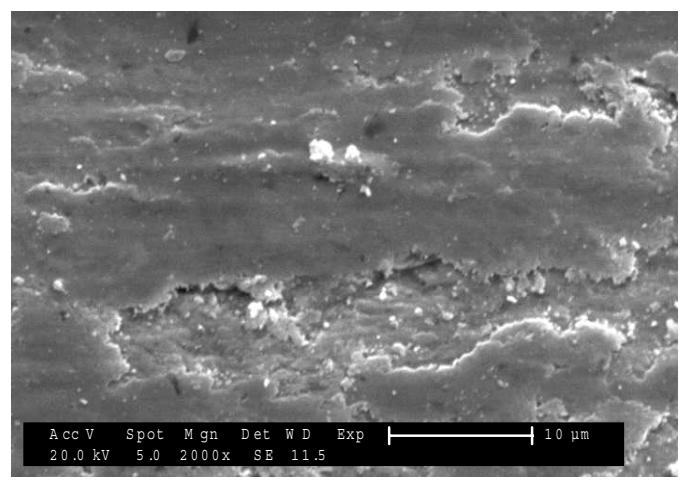

Rajah 10 Pembentukan tampalan pindah pada permulaan pembrekan. Sampel A1 $(\times 2 \mathrm{~K})$, beban kenaan $100 \mathrm{~N}$ dan masa pembrekan 3 minit.

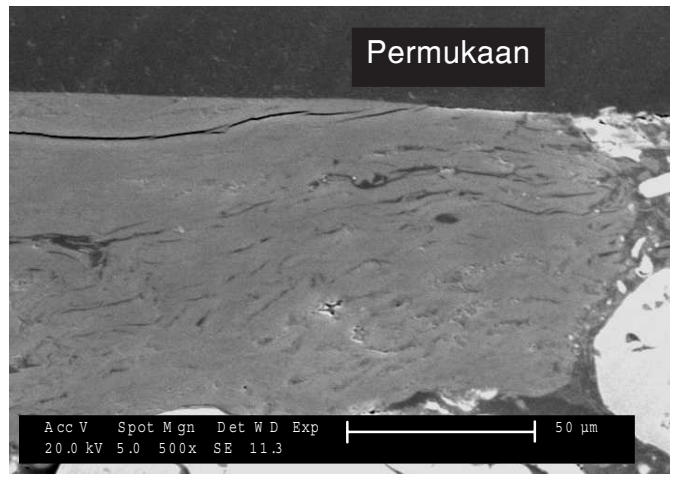

Rajah 9 Lapisan pindah mengandungi bahan logam Fe, Mg, Si, dan Ti. Sampel D4 (× 700), beban kenaan $600 \mathrm{~N}$ dan masa pembrekan 12 minit.

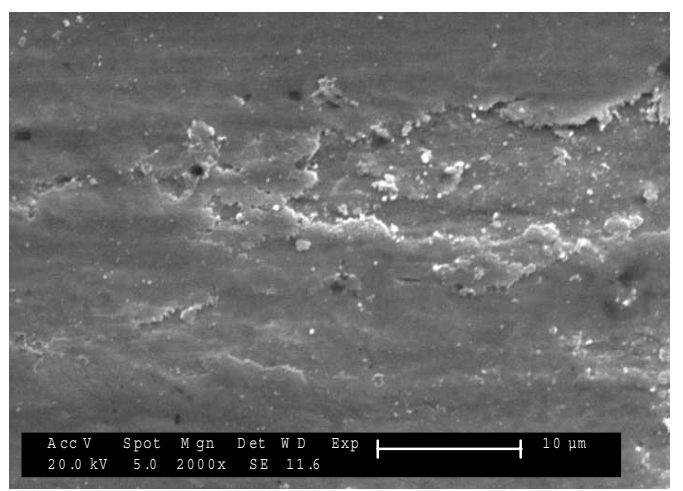

Rajah 11 Peningkatan masa pembrekan menyebabkan tampalan pindah dipepat dan diricih pada permukaan haus. Mekanisme perekat ringan. Sampel A2 $(\times 2 \mathrm{~K})$, beban kenaan $100 \mathrm{~N}$ dan masa pembrekan 6 minit.

pindah meningkat dengan masa pembrekan (Rajah 11) dan beban kenaan (Rajah 12) disebabkan oleh peningkatan kadar pindah dua hala serpihan bahan. Liu et al. [11]; Jain dan Bahadur [12] melaporkan bahan akan tertanggal dari permukaan berkemungkinan meningkat dengan peningkatan tekanan sentuhan. Penyingkiran logam turut meningkat dengan masa gelangsar [13]. Sementara Liu et al. [11] pula mendapati ketebalan lapisan meningkat apabila keadaan ujian semasa gelangsar adalah intensif seperti masa pembrekan yang lama, beban kenaan dan kelajuan yang tinggi. Peningkatan masa pembrekan dan beban kenaan menyebabkan suhu permukaan meningkat [14]. Suhu yang tinggi menyebabkan kekuatan permukaan bahan menurun [15]. Fenomenon ini turut menyebabkan peningkatan pembentukan lapisan pindah. 


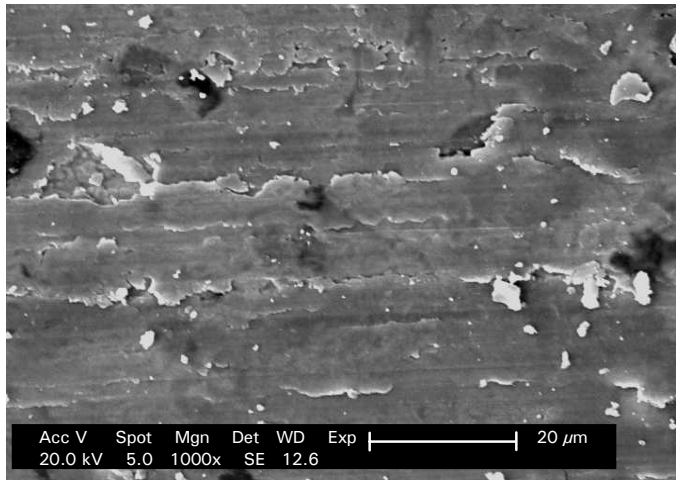

Rajah 12 Puncak gerutu menjadi tumpul dan pada masa yang sama tampalan pindah tericih dan tercalit di atas permukaan haus. Sampel C2 $(\times 1 \mathrm{~K})$, beban kenaan $400 \mathrm{~N}$ dan masa pembrekan 6 minit.

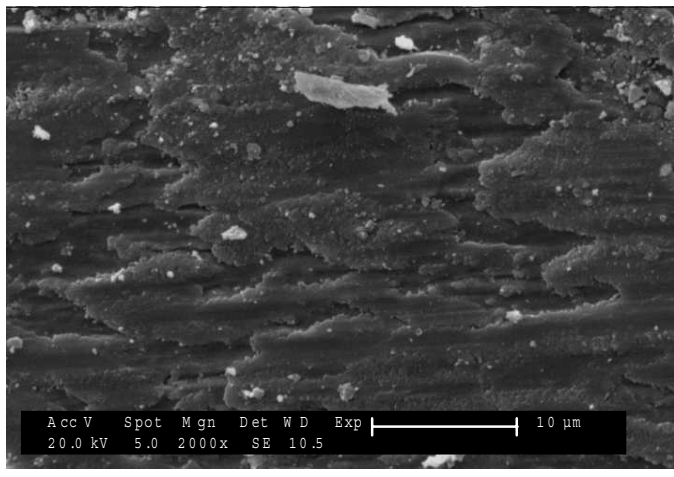

Rajah 14 Peningkatan masa pembrekan menyebabkan pembentukan lapisan pindah berbilang. Mekanisme haus perekat intensif. Sampel D3 $(\times 2 \mathrm{~K})$, beban kenaan $600 \mathrm{~N}$ dan masa pembrekan 9 minit.

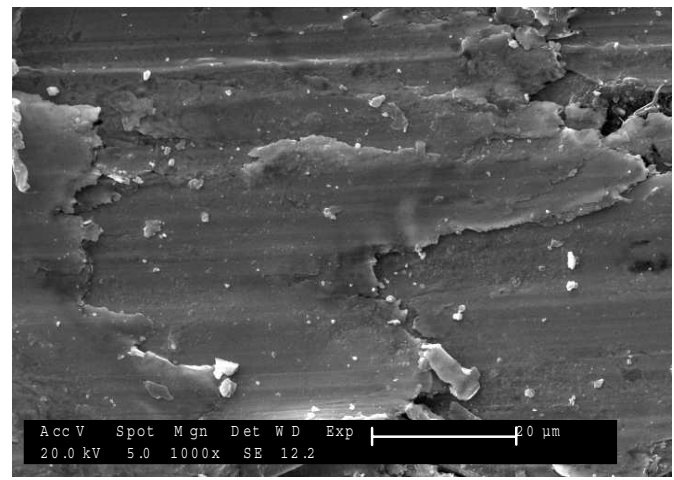

Rajah 13 Peningkatan masa pembrekan menyebabkan lapisan pindah dimampat dan diricih mengikuti arah gelangsar. Sampel A4 ( $x$ $1 \mathrm{~K})$, beban kenaan $100 \mathrm{~N}$ dan masa pembrekan 12 minit.

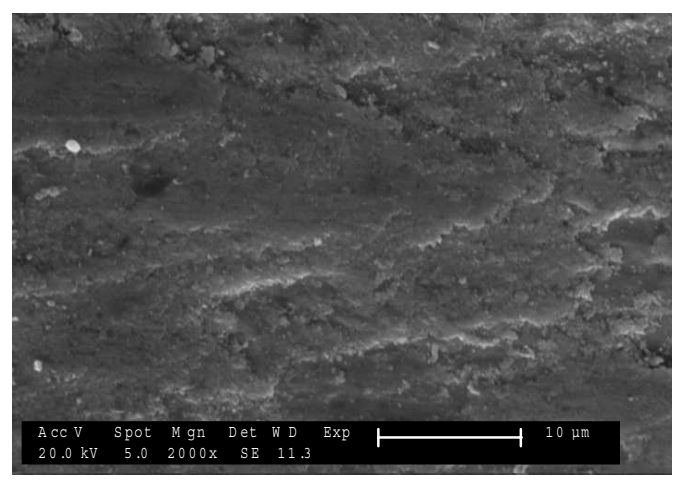

Rajah 15 Pembentukan lapisan pindah berbilang meningkat dengan masa pembrekan. Sampel B4 $(\times 2 \mathrm{~K})$, beban kenaan $200 \mathrm{~N}$ dan masa pembrekan 12 minit.

Lapisan pindah terjana dan tericih secara berterusan di antara muka pad brek dan piring brek semasa pembrekan. Lapisan pindah akan terpisah dan merekat kepada kedua permukaan yang bergelangsar apabila tindakan ricihan melebihi kekuatan ikatan menjelekit lapisan pindah. Sebahagian zarah haus yang tertanggal dari permukaan berkemungkinan akan terperangkap di antara dua pemukaan. Lapisan pindah berbilang terjana hasil daripada pemampatan zarah haus dan penjanaan lapisan pindah yang berulang di atas permukaan. Peningkatan masa pembrekan seterusnya menyebabkan berlaku penjanaan lapisan pindah berbilang pada permukaan pad brek. Masa pembentukan lapisan pindah berbilang bergantung dengan masa pembrekan dan beban kenaan yang dikenakan. Pada beban kenaan 100 N, lapisan berbilang 
mula terjana pada pembrekan selama 12 minit (Rajah 13). Lapisan pindah berbilang berlaku lebih awal iaitu pada masa pembrekan selama 9 minit apabila beban kenaan yang dikenakan melebihi $200 \mathrm{~N}$ (Rajah 14). Lapisan pindah berbilang tericih dan terpepat menutupi permukaan haus secara keseluruhan mengikut arah gelangsar (Rajah 15).

Ubah bentuk plastik teraruh meningkat dengan masa pembrekan dan beban kenaan. Suhu permukaan turut meningkat pada keadaan ini. Fenomenon ini menyebabkan berlaku aliran plastik pada lapisan pindah. Rhee dan Ludema [16] mencerapkan lapisan pindah memaparkan sifat aliran bendalir pada suhu yang tinggi. Kajian mikrostruktur bahan yang dikaji menunjukkan aliran plastik mula berlaku pada beban kenaan 600 $\mathrm{N}$ dengan masa pembrekan selama 12 minit (Rajah 16). Pada masa ini suhu permukaan yang dirakamkan ialah $510^{\circ} \mathrm{C}$. Walau bagaimanapun, suhu cucuh permukaan adalah melebihi takat lebur bahan bagi membolehkan fenomenon ini berlaku. Apabila beban

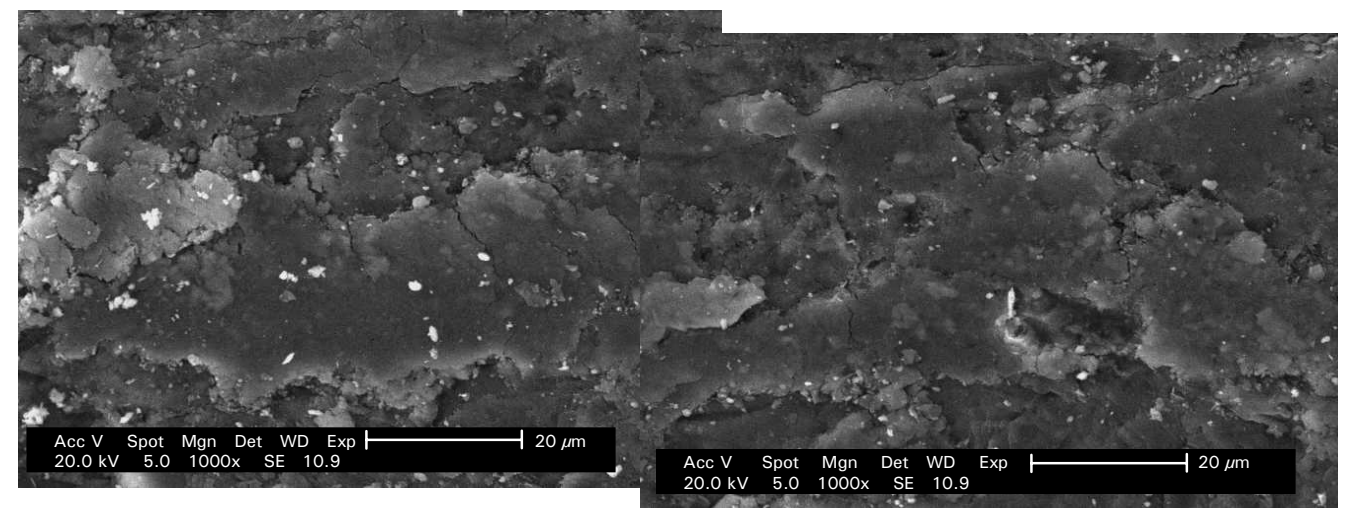

Rajah 16 Peningkatan beban kenaan seterusnya menyebabkan berlakunya aliran plastik pada permukaan pad brek. Sampel D4 $(\times 1 \mathrm{~K})$, beban kenaan $600 \mathrm{~N}$ dan masa pembrekan 12 minit.

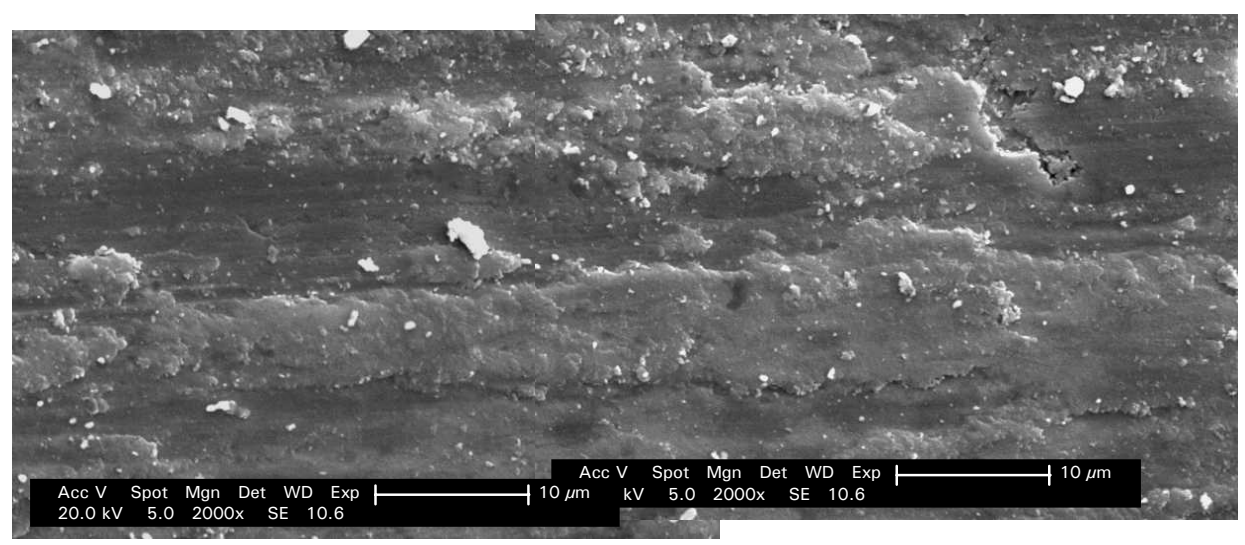

Rajah 17 Pada beban kenaan $800 \mathrm{~N}$ aliran plastik berlaku lebih awal pada masa pembrekan 9 minit. Sampel E3 $(\times 2 \mathrm{~K})$, beban kenaan $800 \mathrm{~N}$ dan masa pembrekan 9 minit. 
kenaan ditingkatkan kepada $800 \mathrm{~N}$ didapati aliran plastik berlaku lebih awal iaitu pada pembrekan selama 9 minit (Rajah 17). Peningkatan masa pembrekan seterusnya menyebabkan aliran plastik bertambah intensif.

Daripada Analisis Tenaga Terserak Sinar-X ke atas lapisan pindah didapati mengandungi bahan logam $\mathrm{Fe}, \mathrm{Al}$, Ti dan $\mathrm{Si}$. Kesemua bahan logam ini mempunyai takat lebur yang tinggi. Oleh yang demikian, adalah dijangkakan suhu cucuh semasa berlakunya proses aliran plastik pada lapisan pindah ini adalah tinggi melebihi takat lebur bahan logam yang dianalisis. Ini dapat disahkan dengan ketiadaan bahan logam yang mempunyai takat lebur yang rendah seperti $\mathrm{Mg}$, Ca dan $\mathrm{K}$ yang telah meruap ke udara.

\subsection{RUMUSAN}

Hasil kajian yang telah dijalankan bolehlah dirumuskan bahawa proses penjanaan lapisan pindah berlaku sepanjang masa pembrekan walaupun beban kenaan ditingkatkan. Darjah penjanaan lapisan pindah bergantung kepada masa pembrekan dan beban kenaan yang dikenakan. Peningkatan beban kenaan dan masa pembrekan yang dikenakan menyebabkan pembentukan lapisan pindah pada permukaan haus bahan geseran brek bertambah intensif. Urutan penjanaan lapisan pindah adalah seperti berikut; (i) penjanaan tampalan pindah, (ii) penjanaan lapisan menutupi permukaan secara menyeluruh, (iii) pembentukan lapisan pindah berbilang, dan (iv) pembentukan lapisan pindah paparan lebur.

\section{PENGHARGAAN}

Kerjasama yang telah diberikan oleh Kakitangan Seksyen Pengujian Produk Mekanikal dan Pusat Teknologi Prestasi Logam, SIRIM Berhad adalah dihargai dalam menjayakan kajian ini.

\section{RUJUKAN}

[1] Talib Ria Jaafar dan Che Husna Azhari. 1997. Ciri Geseran dan Haus. Journal of Industrial Technology 6 (1): 29-46.

[2] Collins, J.A. 1981. Failures of Materials in Mechanical Design: Analysis, Prediction and Prevention. New York: John Wiley and Sons.

[3] Chen, L.H. dan D.A. Rigney. 1985. Transfer During Unlubricated Sliding of Selected Metal Systems. Wear 59: $213-221$.

[4] Ludema, K.C. 1992. Sliding and Adhesive Wear. Dlm. Henry, S.D. (Ed.). ASM Handbook. 18. Friction, Lubrication, and Wear Technology, hlm. 236-241. USA: American Society for Metals.

[5] Jacko, M.G., P.H.S. Tang dan S.K. Rhee. 1984. Automotive Friction Materials Evaluation During the Past Decade. Wear 100: 503-515.

[6] Siwei, Z. 1991. Studies in Non-asbestos Friction Materials: A Brief Review. Dlm. Boqun Wu (pnyt.). Mechanical Properties Materials Design, hlm. 403-411. Amsterdam: Elsevier Science Publisher.

[7] Akagaki, T. dan D.A. Rigney. 1991. Sliding Friction and Wear of Metals in Vacuum. Dlm. Ludema, K.C. dan Bayer, R.G. (Ed.). Wear of Materials, hlm. 265-275. New York: American Society of Mechanical 
Engineers.

[8] Rigney, D.A. 1992. Some Toughts in Sliding Wear. Wear 152: 187-192.

[9] Rigney, D. A. 1997. Comments on Sliding of Metals. Tribology International: 30(5): 361-367.

[10] Talib Ria Jaafar. 2001. Penelitian Permukaan Haus serta Pukal Bahan Geseran Automotif. Tesis Ph.D. UKM. Malaysia.

[11] Liu, T., S.K. Rhee dan K.L. Lawson. 1979. A Study of Wear Rates and Transfer Films of Friction Materials. Dlm. Glaeser, W.A., dan Rhee, S.K. (Ed.). Wear of Materials, hlm. 552-554. New York: American Society of Mechanical Engineers.

[12] Jain, V.K. dan S. Bahadur. 1977. Material Transfer in Polymer Sliding. Dlm. Glaeser, W.A., Ludema, K.C. dan Rhee, S.K. (Ed.). Wear of Materials, hlm. 487-493. New York: American Society of Mechanical Engineers.

[13] Kerridge, M. dan J.K. Lancaster. 1956. The Stages in a Process of Severe Metallic Wear. Proc. Royal Soc. A 236, hlm. 466-483.

[14] Talib Ria Jaafar dan Che Husna Azhari. 2000. Malaysian Science dan Technology Congress 2000, 7 - 9 Nov 2000. Genting Highland.

[15] Buckley, D. H. 1981. Surface Effects in Adhesion, Friction, Wear and Lubrication: 249-250. Amsterdam: Elsevier.

[16] Rhee, S.K. dan K.C. Ludema. 1978. Mechanism of Formation of Polymeric Transfer Films. Wear 46: 231246. 